\title{
SIMPLE AND PARTIAL CORRELATIONS BETWEEN THE EPITHELIAL TISSUE CONTENT OF THE THYROID, THE BODY WEIGHT, AGE, AND LEVEL OF MILK YIELD IN AYRSHIRE COWS
}

\author{
VAPPU Kossila \\ with technical assistance from KaArina Heliander \\ Department of Animal Husbandry, University of Helsinki
}

Received March 19, 1969

A reciprocal relationship occurs between the level of thyroxine in blood and the intensity of TSH secretion from the anterior pituitary. If the synthesis and release of thyroxine within the thyroid gland is in some manner (as a result of iodine deficiency, goitrogens, enzyme defects) inhibited or retarded, the blood thyroxine level will eventually decrease and, as a consequence, the TSH release rate from the pituitary will increase above normal. This, in turn, results in hypertrophy and hyperplasia of the thyroid. Under these conditions a hyperplastic thyroid may prove to be an indicator of an inadequate rather than an increased thyroxine secretion rate. It is known that thyroxine is essential in maintaining efficient milk secretion (TURNer 1968). Furthermore, it is quite possible that a greatly increased TSH secretion may interfere with the synthesis and release of other anterior pituitary hormones needed for maintaining an optimal secretion of milk.

SWETT et al. (1955, p. 31) observed significant positive correlation between the relative thyroid weights and the milk and butterfat yields in Jerseys but not in Holsteins and Guernseys. In the study of KossiLA (1967, p. 73), the thyroid weight of the cows was positively and significantly correlated with the body weight and age, while it was negatively and nonsignificantly correlated with the milk yield, when the body weight and age were held constant. However, compared to the weight of the thyroid, the epithelial tissue content of the gland is probably a more reliable indicator of the thyroxine secretion rate or of the intensity of the TSH stimulation on the thyroid gland (TAla 1952, Uotila \& Kannas 1952, LAmberg 1953). The purpose of this study was to find out whether there were any significant correlations between the absolute amount of epithelial tissue contained in the thyroid gland of the cows and their body weight, age, and capacity of milk production. 
The thyroid material was obtained from 141 Ayrshire cows discarded from the dairy herd of the Viik Experimental Farm during the years 1958 - 59 (group I) and 1960 - 65 (group II). It should be pointed out that some of the cows had received hardly any or no supplemental iodine in their diet (group I) and some had been given supplemental iodine in their diet periods ranging from some months to several years (group II) during their productive lifetime.

Feeding and management of the herd, data concerning the cows, and the methods used in estimating the live weight and corrected body weight, the average daily fat-corrected milk yield (FCM) during the productive lifetime of the cows, etc., have been explained in detail earlier (Kossila 1967, p. 32-40).

After first estimating the percentage of epithelial tissue in the thyroid (E \%) by the method of Uotila \& Kannas (1952), the absolute amount of epithelial tissue in grams contained per gland $(\mathrm{Eg})$ was calculated by using $\mathrm{E} \%$ and the fresh weight of the thyroid gland. The coefficients of simple and partial correlations were calculated according to Croxton \& Cowden (1955).

Before calculating the coefficients of simple and partial correlations, the data obtained from 141 cows were grouped indentically with those of the previous study (Kossila 1967, p. $71-73)$. The $\mathrm{Eg}\left(\mathrm{X}_{1}\right)$ was considered as a dependent variable, and the live weight in $\mathrm{kg}\left(\mathrm{X}_{2}\right)$, or the corrected body weight in $\mathrm{kg}\left(\mathrm{X}_{\mathrm{2}_{\mathrm{a}}}\right)$, the age in months $\left(\mathrm{X}_{3}\right)$, and the average daily FCM yield during the productive lifetime of the cow in $\mathrm{kg}\left(\mathrm{X}_{4}\right)$, as independent variables. At first, the coefficients of the simple and partial correlations were calculated separately for the growing cows $(\mathrm{N}=72)$, for the full-grown cows $(\mathrm{N}=69)$, and for all cows $(\mathrm{N}=141)$ belonging to groups I + II. These results are presented in Table 1A. Subsequently, the respective correlations were calculated for the growing $(N=51)$, for the full-grown $(\mathrm{N}=55)$ and for all cows $(\mathrm{N}=106)$ belonging to group II. The results are presented in Table 1B. Since group I consisted of only 35 cows (21 growing and 14 full-grown), it seemed pointless to calculate similar correlations separately for such a small group. It was thought that the effect of the cow material belonging to group I could become apparent in the results obtained from the entire material, i.e. from those obtained for groups I + II (Table 1A).

\section{Results}

Effect of body weight. Results in Table 1 show that the body size was postitively correlated with the $\mathrm{Eg}$, and that the coefficients of the simple and partial correlations in question were more significant between the corrected body weight and the Eg $\left(\mathrm{r}_{12 \mathrm{a}}\right.$ etc.) than between the live weight and the $\mathrm{Eg}\left(\mathrm{r}_{12}\right.$ etc.), and also more significant in groups I + II (especially in growing cows) than in group II.

$\mathrm{E} f \mathrm{fe} \mathrm{ct}$ of a g e. All of the coefficients of simple and partial correlations between the Eg and the age of the cow $\left(\mathrm{r}_{13}\right.$ etc.) were nonsignificant, indicating that age had little effect on the Eg.

E ffe c t of milk y i e ld. In groups I + II the coefficients of simple and partial correlations obtained between the milk yield and the $\mathrm{Eg}\left(\mathrm{r}_{14}\right.$ etc.) were negative. They 


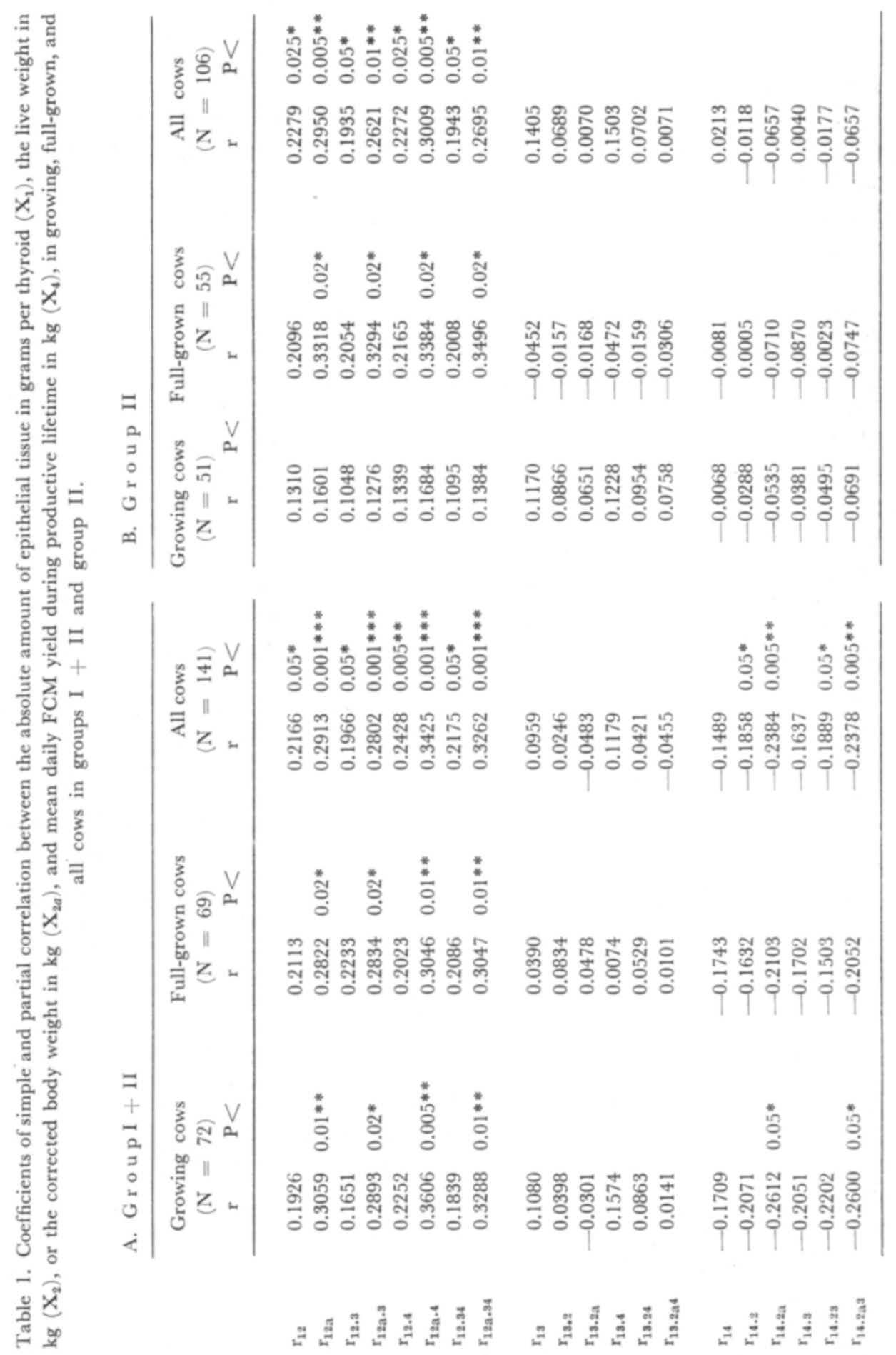


were significant a) in growing cows when the corrected body weight was one of the independent variables held constant $\left(\mathrm{r}_{14 \cdot 2 a}\right)$, and $\left.\mathrm{b}\right)$ in all cows when the live weight $\left(\mathrm{r}_{14 \cdot 2}\right)$ or the corrected body weight $\left(\mathrm{r}_{14 \cdot 2 a}\right)$ was one of the independent variables held constant (Table 1A). On the other hand, in group II, the coefficients of simple and partial correlations between the milk yield and the Eg were mostly negative, very low and, in consequence, also nonsignificant (Table 1B).

\section{Discussion}

Further details (weight and epithelial tissue content of the thyroid, body weight, age, milk yield, etc.) concerning the present cow material can be found in a previous study (Kossila 1967 pp. $71-80$ ) to which this paper is a direct continuation.

It was found that the Eg was more closely correlated with the corrected body weight than with live weight of the cows (Table 1A \& B). Similar phenomena were previously noted in cases of the thyroid weight (KossiLa 1967), the blood and plasma volumes, and the milk yield of cows (writer's observations). Obviously, in this kind of study, for which material has been collected during a period of several years, it is beneficial to use the corrected body weight, i.e. to make the corrections for the stage of gestation and/or for the degree of fatness to the live weight since these corrections reduce the source of variation in the body weight of the cows.

Pregnancy influences the body weight of the cows mainly during the last half of gestation, and about 15 per cent of the cows in the present material (group I + II) were in this category. It has been noted that in 62 dairy cows, slaughtered from the same herd while pregnant from 80 to 265 days, the stage of gestation had practically no effect on the $\mathrm{Eg}$ when the body weight and milk yield were held constant (writer's observation). Furthermore, there is evidence that the thyroid of the bovine fetus is functional during the latter half of the gestation being obviously able to supply the thyroxine needed for the development of the fetus itself (Spielman et al. 1944, Spielman et al. 1945, WolfF et al. 1949), and so the dam's thyroxine is not necessarily required for this purpose.

Corrections for the degree of fatness were made to the body weights of approximately 80 per cent of all the cows in the present study (groups I + II). The amount of body fat increases as a result of a surplus in the energy intake, and this phenomenon occurs usually only after the peak lactation period has been passed. It is also well known that a hypothyroid state favors fattening. Evidently, the corrected body weight indicated more closely than the live weight the metabolic size of an animal. Presumably there is a reciprocal relationship between the thyroxine secretion rate and the accumulation of body fat during the lactational cycles in dairy cows. In fact, when the characteristics of the thyroid are compared with the body size of the animal, it seems more justifiable to use the body weight corrected also for the degree of fatness than the live weight.

A very useful observation was made during the study, namely that in cows age had hardly any effect on the Eg (Table 1A \& B). Apparently the amount of thyroidal epithelium increases primarily during the early parts of life, i.e. before a heifer becames a cow. The weight of the thyroid, in turn, was significantly influenced by age, especially in full-grown cows, this being mainly due to the accumulation of colloid (Kossila 1967, p. 78-79). A significant decrease in the Eg was noted after supplemental iodine had been added into 
the diet of the cows (Kossila 1967a). On the basis of the results of this and the two last mentioned studies, it seems that the Eg in the thyroid is a more reliable indicator of goitre than the weight of the gland, especially if cow-material is used. The fact that the body size has some influence on the Eg does not present a problem since the body size can be easily estimated. Determination of the age on the other hand, especially in randomly selected slaughterhouse material, is difficult.

In groups I + II, the Eg was negatively correlated with the milk yield (Table 1A). This correlation was significant in the growing cows and in all cows, particularly when the corrected body weight was held constant $\left(\mathrm{r}_{14 \cdot \mathbf{2}_{a}}\right)$. The phenomenon is apparently ascribable to the cowmaterial in group I which was added to group II (Table 1A), because the corresponding coefficients of correlation in group II alone (Table 1B) were very low and thus no longer significant. It should be mentioned that cows in group I, many of which had exhibited signs of goiter (see Kossila 1967, p. 87-89), had received hardly any or no supplemental iodine in their diet. The cows in group II had smaller thyroids and had received supplemental iodine during a period of some months to several years of their productional life time. The Eg in the thyroids of the cows in group I was significantly higher, and the milk yield significantly lower, than correspondingly in group II (Kossila 1967a). The last cow in group II was slaughtered late in 1965. Since 1965, more thyroid material has been obtained from the same herd, i.e. group III (ref. Kossila 1969 in press), in which a further normalization in the characteristics of the thyroid gland was noted.

It is well known by now that certain nutritional factors interfere with the attempts to interpret the thyroid activity in cows on the basis of the morphological characteristics of the gland. If it were possible to eliminate the said nutritional factors, the morphological characteristics of the thyroid might become more reliable and informative as far as the secretory function of the thyroid and the hormonal balance in the animals are concerned.

\section{Su m mary}

The absolute amount of the epithelial tissue in the thyroid (Eg) of cows was significantly and more closely correlated with the body weight corrected for pregnancy and/or degree of fatness than with the live weight. Age had practically no effect on the Eg, this observation being of value in case cows of various ages are to be used as material in studies on the incidence of endemic goitre. Due to a group of goitrous cows in the investigated material, significant negative correlation was obtained between the $\mathrm{Eg}$ and the milk yield. The implications of this discovery are discussed.

Acknowledgements. This study has been financed by a grant from the August Johannes and Aino Tiura's Foundation. 


\title{
REFERENCES
}

Croxton, F. E. \& Cowden, D. J. 1955. Applied general statistics. 2nd ed. Pitman, London. XVI +843 pp. Chapt. 21.

Kossit. , V. 1967. On the weight and basic structural components of the thyroid in dairy cattle. Acta Agralia Fennica 109. 2 pp. 115.

-»— 1967a. Jodintarpeen tyydyttämisen merkitys lypsylehmien ratvitsemuksessa. Maatal. ja Koetoim. 21: 228-233.

- - 1969. On the development of the thyroid weight in the dairy herd of the Viik Experimental Farm. J. Sci Agr. Soc. Finland 41:149-153.

LAMBERG, B-A. 1953. Radioactive phosphorus as indicator in a chick assay of thyrotropic hormone. Acta Med. Scand. Suppl. 279.

Spielman, A. A., Petersen, E. E. \& Fitch, J. B. 1944. The effect of thyroidectomy on lactation in the bovine. J. Dairy Sci. 27: 441-448.

-» - et al. 1945. General appearance, growth and reproduction of thyroidectomized bovine. Ibid. 28: 239.

Swett, W. W., Matthews, C. A. \& Forman, M. H. 1955. Weight of thyroid in dairy cows from different geographical areas within the United States. U.S. Dept. Agr. Techn. Bull. 1123.

TALA, P. 1952. Histoquantitative studies on the effect of thyrotropin and thyroxin on the morphology of the thyroid gland, with special reference to standardization of the thyrotropic hormone. Acta Endocrin. 10, suppl. 9.

Wolff, J., Chaikoff, I. L. \& Nichols, C. W. 1949. The accumulation of thyroxine-like and other iodine compounds in the fetal bovine thyroid. Endocrin. 44:510-519.

Uotil., U. \& Kannas, O. 1952. Quantitative histological method of determining the proportions of the principal components of thyroid tissue. Acta Endocrin. 11:49-60.

\section{SELOSTUS}

KILPIRAUHASEPITEELISOLUKON MÄÄRÄN, ELOPAINON TAI MUUNNETUN ELOPAINON, IÄN JA MAIDONTUOTANTOKYVYN VÄLISET YKSINKERTAISET JA OSITTAISVUOROSUHTEET AYRSHIRE-LEHMILLÄ

\author{
Vappu Kossila ja KaArina Heliander \\ Helsingin yliopiston kotieläintieteen laitos
}

Tutkimusaineisto käsitti 141 Viikin opetus- ja koetilan karjasta vuosina 1958-59 (I) ja $1960-65$ (II) poistettua lehmää. Näiden kilpirauhasista oli määritetty epiteelisolukon absoluuttinen määrä grammoina (Eg). Eg:n arvellaan edullisissa olosuhteissa kuvaavan kilpirauhastoiminnan aktiivisuutta. Lehmien elopainoon oli tehty tiineysastetta ja/tai lihavuusastetta edellyttävät korjaukset ns. muunnetun elopainon määrittämiseksi. Ikä oli laskettu kuukausina ja tuotos tuotannollisen elinkauden keskimääräisenä 4-prosenttiseksi muunnettuna maitotuotoksena.

Kiinteimmät vuorosuhteet todettiin $\mathrm{Eg}: \mathrm{n}$ ja muunnetun elopainon välillä. Ikä ei näyttänyt juuri lainkaan vaikuttavan $\mathrm{Eg}$ :hen.

Koko 141 lehmää käsittävässä aineistossa (I + II) Eg oli merkittävästi negatiivisessa vuorosuhteessa maitotuotokseen silloin kun lehmän elopaino tai muunnettu elopaino pidettiin vakiona. Sensijaan vuosina 1960-65 (II) poistetuilla lehmillä ko. vuorosuhde oli merkityksetön. Tulosten tarkastelussa päädyttiin siihen, että määrätyt ravintotekijät ovat vaikuttaneet häiriöllisesti yrityksiin tulkita kilpirauhasaktiviteettia rauhasen morfologisten ominaisuuksien, ja näistä erityisesti $\mathrm{Eg}$ :n perusteella. 